\title{
Slow recovery from disturbance: a 20 year study of Ascophyllum canopy clearances
}

\author{
A. INGÓLFSSON ${ }^{1}$ AND S.J. HAWKINS ${ }^{2}$ \\ ${ }^{1}$ Institute of Biology, University of Iceland, Sturlugata 7, IS-101 Reykjavík, Iceland, ${ }^{2}$ Head of College of Natural Sciences, Memorial \\ Building, University of Bangor, Bangor Gwynedd, LL57 2UW
}

\begin{abstract}
We describe an experiment where Ascophyllym nodosum was removed from two $1 \times 1 \mathrm{~m}$ plots in south-western Iceland in August 1985. The plots were studied regularly until 2005. Recovery of the Ascophyllum canopy took 7-8 years. The understorey algae in one of the plots consisted mostly of extensive growth of Cladophora rupestris, which died within a year of Ascophyllum clearance. No Cladophora had reappeared by 2005, although it was healthy and abundant in control plots throughout the study period. Thus even after 20 years the community had not recovered from disturbance.
\end{abstract}

Keywords: Ascophyllym removal, slow recovery, Iceland

Submitted 29 November 2005; accepted 14 December 2007

The seaweed Ascophyllum nodosum is a dominant canopyforming alga on rocky shores in the northern North Atlantic, frequently forming monospecific stands at sheltered sites. Its role as a habitat forming species has long been recognized, and its interaction with other shore organisms has been studied by various experimental manipulations. Such experiments have typically had a duration of only a few years (e.g. Bertness et al., 2002), the maximum to our knowledge being 12 years (Jenkins et al., 2004). Here we report on 20 years of observations following removal of Ascophyllum in Iceland showing very slow recovery from disturbance, especially of understorey algae.

On 22 August 1985 we removed Ascophyllum nodosum from two plots (1 and 2) on steep, flat lava blocks at the High-Salinity Lagoon of Ósar, south-western Iceland $\left(63^{\circ} 56.3^{\prime} \mathrm{N}-22^{\circ} 40.0^{\prime} \mathrm{W}\right)$. The shore is extremely sheltered, with Ascophyllum nodosum forming a monospecific canopy with close to $100 \%$ cover of the midshore. Its large epiphyte Polysiphonia lanosa is present in moderate but varying quantities. The plots were $1 \times 1 \mathrm{~m}$, their upper side coinciding with a sharp A. nodosum/Fucus spiralis boundary. In plot 1 there was considerable understorey cover of Cladophora rupestris and crustose corallines and some scattered Chondrus crispus plants, all of which were left untouched. Repeated detailed examination of the surrounding area during 1986-2004 showed this species composition to be typical of the upper Ascophyllum zone of this site. On plot 2 no algae were seen under Ascophyllum; instead the rock was covered with a thin layer of mud; this was not observed elsewhere in the area. Similarly sized areas adjacent to each of the experimental plots were designated as controls.

Following Ascophyllum removal, the plots were examined again 12 days later, on 3 September 1985. On plot 1 all Chondrus plants appeared bleached and dead, and so did much of the Cladophora. Each species was healthy in the

Corresponding author:

Agnar Ingólfsson

Email: agnaring@hi.is adjacent control plot and surrounding area. On 11 October 1985 both Chondrus and crustose corallines appeared dead in plot 1 , while only occasional Cladohora plants were still green. The control plot was unchanged. There was no longer any mud on plot 2, but this was still present in the adjacent control plot.

The central parts, measuring 0.4 × $0.4 \mathrm{~m}$, of experimental plots 1 and 2 were then checked yearly from 1986 to 2005, with the exceptions of 1996 and 1998. Observations were made from late April to late June in 1986-1990, but from mid September to late November thereafter. A $0.6 \times 0.6 \mathrm{~m}$ frame was laid on the plot. The frame had criss-crossing nylon threads at $10 \mathrm{~cm}$ intervals, forming 25 intersections. The species underlying each intersection were noted. The control plots were at first only examined in a qualitative way, but from 1992 on they were examined in the same way as the manipulated plots. The cover of Polysiphonia lanosa was not measured prior to 1992. Crustose corallines and red encrusting algae (primarily Hildenbrandia protypus) were mostly ignored due to frequent difficulties in distinguishing them from bare rock.

Figure 1 shows recolonization. In both plots Fucus vesiculosus had reached $100 \%$ cover in 1988, 3 years after Ascophyllum nodosum removal; this cover was maintained for 2 (plot 2) and 4 (plot 1 ) years before starting to decline rapidly, coinciding with an increase in Ascophyllum. The last vestiges of $F$. vesiculosus were seen in 1997 on plot 1 and in 1994 on plot 2, although it reappeared there in 2001, 2003 and 2004 in small patches within the Ascophyllum. Similar patches also appeared in the controls, coincident with small decreases in the Ascophyllum canopy. Ascophyllum had reached $100 \%$ cover in 1991 in plot 2 and by 1993 in plot 1 . No living Cladophora rupestris were seen on plot 1 from 1986 onwards, except for a trace in 1989. Chondrus crispus finally appeared in small quantities in 2002. Both species were present in the control for plot 1, initially in 1985 and from 1992 onwards when checked. Chondrus crispus was occasionally seen on plot 2 and its control. Mud did not reappear on plot 2 until 1989. Ulva was occasionally observed in small quantities in experimental plots 1 and 2 and their controls, but in most years these algae were not seen. 


\section{Plot 1}
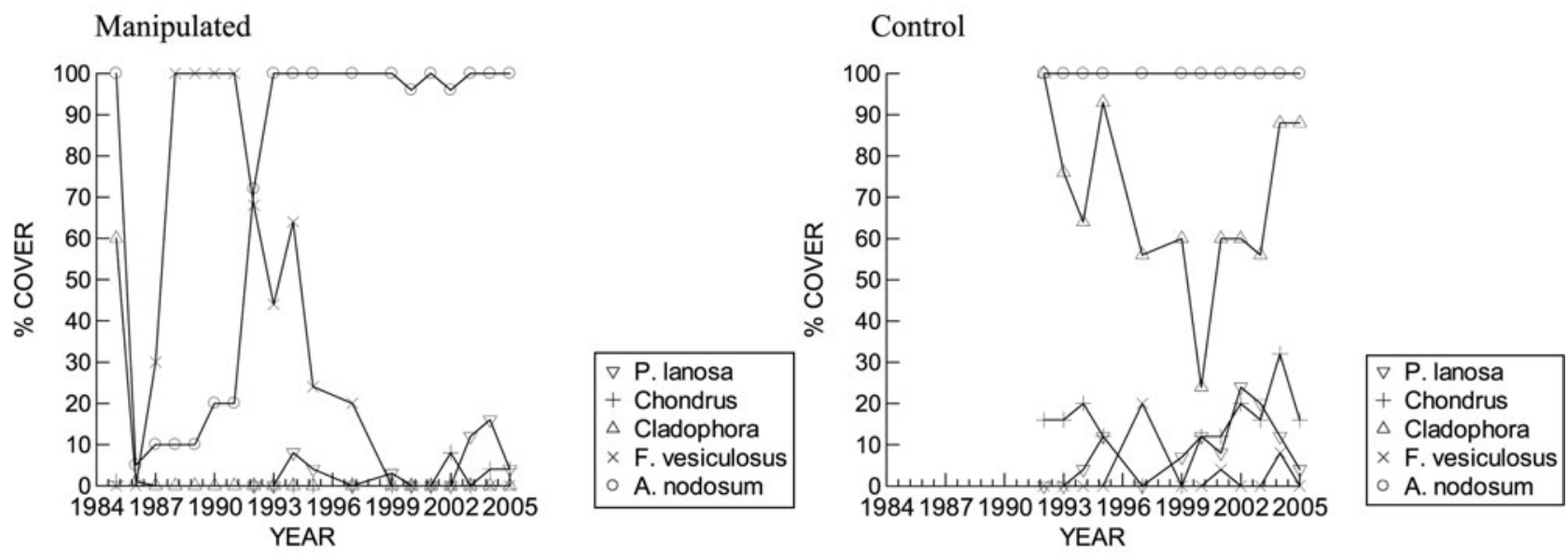

\section{Plot 2}

\section{Manipulated}

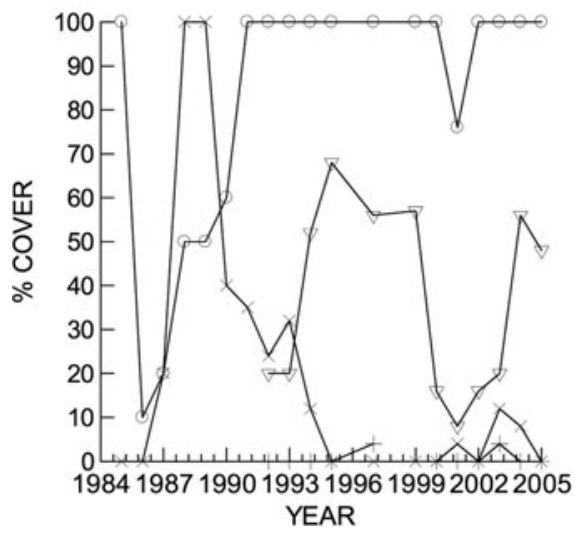

\section{Control}

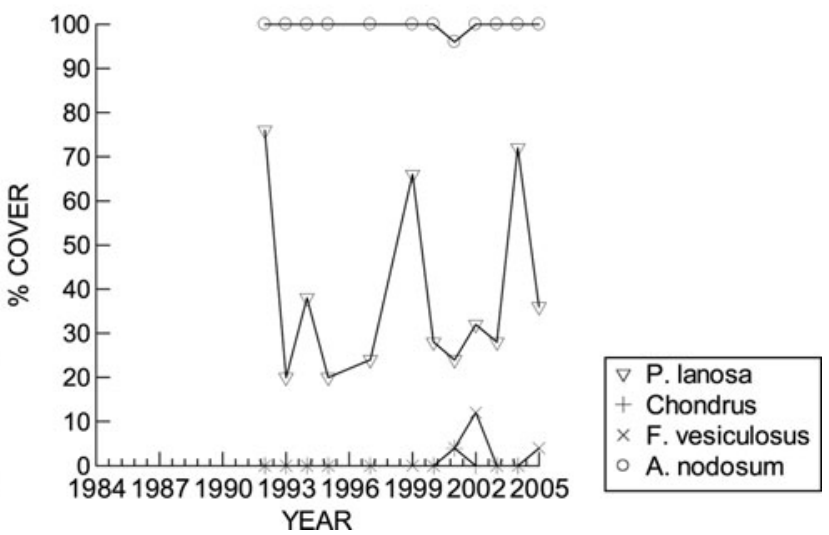

Fig. 1. Percentage cover of canopy and main undercover algae on 2 experimental plots and their control plots at Ósar, south-western Iceland, $1985-2005$. Ascophyllum nodosum was removed from an area of $1 \times 1 \mathrm{~m}$ of experimental plots in August 1985. Control plots received only a cursory examination up to 1992. The epiphyte Polysiphonia lanosa was ignored up to 1992. Cover measurements were made in the central $0.4 \mathrm{x} 0.4 \mathrm{~m}$ of each plot.

In both experimental plots Fucus spiralis colonized the upper quarter or so of the Ascophyllum removal area, its lower limit being conspicuously lower there than in the untreated surroundings. This was noticeable up to 1990 (plot 2) and 1991 (plot 1). This was outside the central area quantitatively examined in each plot. This suggests the lower limit of F. spiralis is set by competition in Iceland as elsewhere (e.g. see Schonbeck \& Norton, 1978; Hawkins \& Hartnoll, 1985 for work in the British Isles).

The early development on the experimental plots after removal of the Ascophyllum canopy was similar to that reported in other studies, with a rapid development of a full Fucus spp. canopy (Keser \& Larson, 1984; Jenkins et al., 1999; Bertness et al., 2002; Cervin et al., 2004), although this appeared to be somewhat slower at Ósar (3 years) than elsewhere (generally less than 18 months). The subsequent full recovery of the Ascophyllum canopy in 6-8 years (as measured by \% cover) appeared to take not much longer than reported elsewhere. Thus, Cervin et al. (2004) found some recovery after 4 years on the west coast of Sweden, and Keser \& Larson (1984) found substantial to virtually complete recovery in the mid-intertidal 5 years after complete removal (scraping and burning) in Maine. However, Jenkins et al. (1999) noted no recovery whatsoever after 6 years in the Isle of Man, and only partial recovery after 12 years, the canopy being still a mixture of Ascophyllum and Fucus spp. The Isle of Man differed from the other sites because of the presence of the limpet Patella vulgata, which is a major grazer and clearly influences succession profoundly, but it is absent from New England and Iceland.

Plot 2 and its control had virtually no understorey vegetation, presumably due to a thin layer of mud. Plot 1 had extensive undercover of Cladophora rupestris and some of Chondrus crispus, apart from crustose corallines. It was obvious that both former species were bleached to death within a few months after canopy removal. There is still no trace of the Cladophora after some 17 years of full canopy (first Fucus, then a mixture, and pure Ascophyllum for some 14 years). Chondrus has finally reappeared, with the first plants being noted in small quantities in 2002. Crustose corallines were mostly ignored but a detailed photographic study in October 2002 clearly showed healthy plants on both plot 1 and 
its control with no apparent difference. One can therefore presume that their recovery was quicker than that of other understorey algae. The only comparable study on the fate of undercover vegetation (red algal turf of Chondrus crispus and several additional species) after canopy removal is that of Jenkins et al. (1999, 2004). The red algal turf showed partial recovery within a few years, but was still not up to its former level 12 years after canopy removal. Jenkins et al. (1999) suggested the limpet Patella vulgata influenced recovery. Neither this grazer nor the large periwinkle Littorina littorea are present in Iceland. However, the grazers Littorina obtusata, Idotea granulosa and Hyale nilssoni are common there, and may somehow have hindered recruitment of the undercover algae. Perhaps an unusual weather event, such as a period of hard frost at spring tides may be sufficient to allow the germlings to escape grazing during a sensitive stage of their lives. Whatever the reason, the lesson from these experiments is that it may take more than 20 years to recover from a disturbance event.

\section{ACKNDWLEDGEMENTS}

S.J.H. was originally funded in 1985 by the Nordic Council for Marine Biology and Ecology to visit Iceland. This paper would not have happened without CORONA workshops (National Science Foundation funded Coordinating Research on the North Atlantic). Thanks to Ms P. Masterson for MS preparation. S.J.H. was funded by NERC GIA to the Marine Biological Association.

\section{REFERENCES}

Bertness M.D., Trussell G.C., Ewanchuck P.J. and Silliman B.R. (2002) Do alternate stable community states exist in the Gulf of Maine rocky intertidal zone? Ecology 83, 3434-3448.

Cervin G., Lindegarth M., Viejo R.M. and Åberg P. (2004) Effects of small-scale disturbances of canopy and grazing on intertidal assemblages on the Swedish west coast. Journal of Experimental Marine Biology and Ecology 302, 35-49.

Hawkins S.J. and Hartnoll R.G. (1985) Factors determining the upper limits of intertidal canopy-forming algae. Marine Ecology Progress Series 20, 265-271.

Jenkins S.R., Hawkins S.J. and Norton T.A. (1999) Direct and indirect effects of a macroalgal canopy and limpet grazing in structuring a sheltered inter-tidal community. Marine Ecology Progress Series 188, $81-92$.

Jenkins S.R., Norton T.A. and Hawkins S.J. (2004) Long term effects of Ascophyllum nodosum canopy removal on mid shore community structure. Journal of the Marine Biological Association of the United Kingdom 84, 327-330.

Keser M. and Larson R. (1984) Colonization and growth of Ascophyllum nodosum (Phaeophyta) in Maine. Journal of Phycology 20, 83-87.

and

Schonbeck M.W. and Norton T.A. (1980) Factors controlling the lower limits of fucoid algae on the shore. Journal of Experimental Marine Biology and Ecology 43, 131-150.

\section{Correspondence should be addressed to:} Agnar Ingólfsson Institute of Biology University of Iceland Sturlugata 7, IS-101, Reykjavík, Iceland email: agnaring@hi.is 